Research article

\title{
SNP GENETIC DIVERSITY WITHIN A FRAGMENT OF THE GENE MYO15A RESPONSIBLE FOR THE HEARING PROCESS IN A POPULATION OF FARMED AND FREE-LIVING ANIMALS OF THE CANIDAE FAMILY
}

\author{
JAKUBCZAK Andrzej, GRYZINSKA Magdalena*, HORECKA Beata, DZIADOSZ \\ Katarzyna, JEZEWSKA-WITKOWSKA Grazyna \\ University of Life Sciences, Faculty of Biology and Animal Breeding, Department of Biological Basis \\ of Animal Production, 20-950 Lublin, Poland
}

(Received 06 March; Accepted 23 April 2014)

\begin{abstract}
The gene MYO15A is involved in the production of a protein included in the group of motor proteins known as myosins. Myosin XVA is located in the inner ear, the pituitary gland and other tissues, and has a substantial influence on the hearing process. Mutations in this gene cause amino acid substitutions in the conserved motor domain of the myosin chain, leading to shortening of the stereocilia in the hair cells, so that the function of myosin XVA is impaired. A research hypothesis was put forth that mutations in the gene responsible for the hearing process in animals of the Canidae family can cause hypoacusis, as well as substantial behavioural changes in dogs (ranging from timidity to aggressive behaviour). The study determined SNP polymorphism in a fragment of the gene $M Y O 15 \mathrm{~A}$, which can cause hearing disorders or hypoacusis, in wild and farmed individuals of the Canidae family.
\end{abstract}

Key words: fox, mutation, MYO15A gene, raccoon dog, SNP haplotype

\section{INTRODUCTION}

The gene MYO15A takes part in the production of the motor protein myosin XVA. The myosin family is divided into 20 classes. Within each class the myosins are also similar in terms of the organization of their tail domains. Many of them have a broad range of phylogenetic expression, e.g. MYO1, 2, 3, 5, 6 and 7 (classes 3 and 6 are expressed only in Metazoa). Some, on the other hand, such as MYO8 and MYO13, have been found only in plants; MYO10 and MYO16 are found in vertebrates, while the other classes have been identified only in one species or in a few related species (MYO4, 12, 14, 17) [1].

Myosins are actin-dependent proteins that bind and hydrolyse ATP, which supplies energy enabling them to move along actin filaments. They perform numerous

\footnotetext{
* Corresponding author: e-mail: magdalena.gryzinska@up.lublin.pl
} 
functions in the cell, e.g. in cytokinesis, endocytosis, exocytosis, muscle contraction, and localization of organelles. Their classification includes conventional myosins, most frequently occurring in muscles, and unconventional ones with diverse structure and functions [2,3]. Most proteins in this group have a similar structure. The motor domain contains actin and ATP-binding regions, preceded by an elastic region containing a binding site for myosin light chains. The $\mathrm{C}$-terminal region of the protein forms the tail structure, which varies in different myosin classes. The protein myosin XVA is included among unconventional myosins and has an elongated $\mathrm{N}$-terminal domain preceding the motor part of the peptide [4].

The main functions performed by myosin XVA are contributing to the development and appropriate size of stereocilia in the inner ear and transporting whirlin to the site of its localization at the tips of the stereocilia. Stereocilia are actin fibres located on the surface of sensory cells in the inner ear. They are responsible for the processes of converting sound waves into nerve impulses and for maintaining balance. They are grouped into bundles joined by actin and fibrin fibres and arranged regularly according to size on the surface of auditory hair cells. In all sensory cells of the inner ear a state of stimulation is achieved via mechanical bending of the stereocilia bundle [5].

Hereditary deafness caused by mutations in the gene MYO15A has been diagnosed in humans, mice and dogs. In humans, the disease is inherited autosomally and recessively and is known as DFNB3. Sixteen mutations in MYO15A contributing to the occurrence of this disorder have been identified. Most of the mutations inducing this form of deafness cause changes in one of the amino acids composing the amino acid chain of the protein myosin XVA, resulting in a non-functional peptide that is too short. The change in the structure of this protein is also associated with shortening of the stereocilia, which leads to hearing loss [3,5]. Two of the mutations identified, located in exon 2 of $M Y O 15 A$, are associated with deafness in people living in India, Pakistan and Turkey, and demonstrate that the long N-terminal chain of myosin XVA is responsible for the normal hearing process [2]. Apart from deafness humans with DFNB3 have no symptoms associated with other parts of the body [4].

The counterpart of DFNB3 in mice is the 'shaker-2' syndrome. Whereas DFNB3 has no symptoms apart from deafness, in mice with shaker-2 syndrome head-tossing and behavioural changes are observed, as well [4]. Mutations in the gene MYO15A cause amino acid substitutions in the conserved motor domain of the myosin chain, which leads to shortening of the stereocilia [6].

Hereditary deafness in dogs is induced by mutations in many genes responsible for normal hearing. A mutation in the gene $M Y O 15 A$ causes shortening of the stereocilia, whereas degeneration of auditory hair cells located in the cochlea causes hearing disorders. This mutation induces similar symptoms to those of DFNB3 in humans and shaker-2 deafness in mice $[7,8]$.

In humans the MYO15A gene has been mapped on sub-band 2 in region 1 of band 1 on the short arm of chromosome 17 (17p11.2), in mice on chromosome 11, and 
in dogs in region 2 on bands 3 and 4 of the long arm of chromosome 5 (5q23-q24). Human MYO15A consists of 66 exons and encodes a protein composed of 3,530 amino acids with a molecular mass of about $395 \mathrm{kDa}$ [2].

The aim of the study was to locate SNP polymorphisms and identify the type of mutations occurring in a fragment of the gene MYO15A among free-living and farmed individuals of the Canidae family, putting forth the hypothesis that they may cause hearing disorders or hypoacusis in this group of animals.

\section{MATERIALS AND METHODS}

\section{Animals}

The material for the study consisted of the blood of farmed red foxes [Vulpes vulpes] (20 individuals) and farmed raccoon dogs [Nyctereutes procynoides] (20 individuals), all from Poland, and raw skins of wild foxes from North America - north-eastern regions of the United States and Canada (20 individuals) - and Poland (20 individuals) and of wild raccoon dogs from Poland (20 individuals).

\section{Genetic and data analysis}

Total genomic DNA was extracted from each sample using a commercial QIAgen extraction kit (QIAamp DNA Blood Mini Kit or DNeasy Blood \&Tissue Kit) following the protocol provided in the QIAcube. The myosin-XV gene [MYO15A] was analysed. The primers were designed using Primer3Plus software [9] to amplify a region of MYO15A as follows: forward 5' 'TT'TCCACATCCACTCTCACG 3' and reverse 5' GAAGGGGGAGAAGCAGACTT 3'. The first amplification was performed by polymerase chain reaction (PCR). The reactions (25 $\mu \mathrm{L}$ total volume) contained $2 \mu \mathrm{l}$ DNA (with $50 \mathrm{ng} / \mu \mathrm{l}$ DNA concentration) and $1.0 \mathrm{U}$ Taq polymerase (Ampli Taq Gold 360 DNA Polymerase, Applied Biosystems) in the manufacturer's buffer, adjusted to a final concentration of $2.5 \mathrm{mM} \mathrm{MgCl} 2,0.2 \mathrm{mM}$ of each dNTP and $0.1 \mathrm{mM}$ of each primer. PCR cycling conditions were $95^{\circ} \mathrm{C}$ for $10 \mathrm{~min} ; 30$ cycles of $95^{\circ} \mathrm{C}$ for $30 \mathrm{~s}, 52^{\circ} \mathrm{C}$ for $60 \mathrm{~s}$ (IGF1 and MYO15A) or $63^{\circ} \mathrm{C}$ for $60 \mathrm{~s}$ (PAX3), $72^{\circ} \mathrm{C}$ for $60 \mathrm{~s}$; and $72^{\circ} \mathrm{C}$ for $20 \mathrm{~min}$. (Labcycler, SensoQuest). To confirm the PCR products, gel electrophoresis was carried out using $2 \%$ agarose gel with ethidium bromide (EtBr). The PCR product was purified using an ExoSAP-IT kit (Affymetrix). The second amplification (sequencing PCR) - bidirectional sequencing - was carried out with the BigDye ${ }^{\circledR}$ Terminator v3.1 CycleSequencing Kit (Applied Biosystems). PCR products were purified using a DyeEx Spin Kit (Qiagen) in the QIAcube. PCR products were sequenced using a 3100 Genetic Analyzer (Applied Biosystems). The sequences were assembled into contigs using DNA Baser (Heracle Biosoft; http:// www.DnaBaser.com). Sequencing results were aligned using BLAST. The sequencing data were then compared with canine reference sequences for the gene MYO15A 
(AJ428858) registered in the EMBL database. The SNP positions of farmed and wild individuals were compared using MEGA4 software. Individual haplotype frequency calculations were performed with the SAS statistical package. A set of single nucleotide polymorphisms (SNPs) located on one chromatid, obtained by sequencing each of the gene fragments studied, was defined as a haplotype.

\section{RESULTS}

The sequenced fragment of the gene $M Y O 15 A$ in the red fox and raccoon $\operatorname{dog}$ was compared with a canine reference sequence (AJ428858). The data obtained are presented in Table 1.

Table 1. Polymorphic nucleotide positions in dog, raccoon dog and fox in the region of the MYO15A gene sequence

\begin{tabular}{lcccccccc}
\hline Species & c.426 & c.432 & c. 445 & c.458 & c.463 & c.522 & c.548 & c.578 \\
\hline dog & A & A & G & A & G & A & G & C \\
raccoon $\operatorname{dog}$ & A & A, G & G & A & G & G & A & C \\
fox & A, G & A & T & G & G, A & G & A & C, A \\
\hline
\end{tabular}

SNP changes at positions c.426, c.432, c.463 and c.578 differentiated the animals into haplotypes within species. Nucleotide polymorphism at positions c.445 and c.458 was noted only for the foxes, while the raccoon dogs had identical nucleotide sequences to those of the dogs. However, SNP polymorphism at positions c.522 and c.548 occurred in raccoon dogs and foxes. Of the eight SNP noted, there were six transitions $(A>G$ and $\mathrm{G}>\mathrm{A})$, and two transversions $(\mathrm{G}>\mathrm{T}$ and $\mathrm{C}>\mathrm{A})$.

A contig was determined in the fox and raccoon dog. The analysed fragment of the gene MYO15 $A$ in foxes was $168 \mathrm{bp}$ in length. Three SNP were noted, including two transitions, at c.426 (A->G) and c.463 (G->A), and one nucleotide transversion at c.578 (C->A). Two mutations were noted in the wild individuals and one in the farmed animals. On this basis four haplotypes (A - D) were distinguished. Haplotypes A and $\mathrm{C}$ were present only in wild foxes living in Poland. Haplotype D had a relatively low frequency, and was present only in wild American foxes (Tab. 2). In farmed foxes one

Table 2. The types and frequency of haplotypes MYO15A gene of foxes

\begin{tabular}{cccccc}
\hline \multirow{2}{*}{$\begin{array}{c}\text { Haplotype } \\
\text { name }\end{array}$} & SNP position & & Haplotype & \multicolumn{2}{c}{ Haplotypes frequency in foxes } \\
\cline { 2 - 2 } & $\begin{array}{c}\text { frequency } \\
\text { in all foxes }\end{array}$ & farm & $\begin{array}{c}\text { wild } \\
\text { [Poland] }\end{array}$ & $\begin{array}{c}\text { wild } \\
\text { [North America] }\end{array}$ \\
\hline reference & A G C & & & & \\
contig & A G C & 0.883 & 0.85 & 0.90 & 0.90 \\
A & A A C & 0.017 & & 0.05 & \\
B & A G A & 0.050 & 0.15 & & \\
C & A R C & 0.017 & & 0.05 & 0.10 \\
D & G G C & 0.033 & & & \\
\hline
\end{tabular}


mutation was detected, at c.578 (C>A), based on which haplotype B was distinguished. This may suggest that mutations occurring in the gene $M Y O 15 A$ in the farmed Canidae individuals analysed may contribute to hearing deterioration in these animals.

The analysed fragment of the gene $M Y O 15 A$ in the raccoon fox was $177 \mathrm{bp}$ in length. In the group of farmed individuals one adenine-to-guanine transition $(A>G)$ was identified at position c.432. Statistical analysis using SAS revealed one haplotype (A). Haplotype A appeared with a frequency of $10 \%$ (Tab. 3).

Table 3. The types and frequency of haplotypes MYO15A gene of raccoon dog

\begin{tabular}{cccccc}
\hline \multirow{2}{*}{$\begin{array}{c}\text { Haplotype } \\
\text { name }\end{array}$} & SNP position & $\begin{array}{c}\text { Haplotype } \\
\text { frequency in all }\end{array}$ & $\tilde{N}$ & & Haplotypes frequency in raccoon dog \\
& $\tilde{f}$ & raccoon dog & farm & wild [Poland] \\
\hline reference & $\mathrm{J}$ & & & \\
contig & $\mathrm{A}$ & 0.95 & 0.90 & 1.00 \\
$\mathrm{~A}$ & $\mathrm{G}$ & 0.05 & 0.10 & \\
\hline
\end{tabular}

\section{DISCUSSION}

Mutations in the gene MYO15A cause congenital deafness in humans (DFNB3) and in mice (shaker-2). Research in humans has demonstrated the presence of two mutations, both of which affected exon 30 in the gene. The first involved a $\mathrm{G}>\mathrm{A}$ transition and a Glu/Arg conversion, and the second a $\mathrm{C}>\mathrm{T}$ transition and Pro/Ser conversion in the amino acid chain [10]. In mice affected by Shaker-2 the hair cells are arranged normally, but are decidedly shorter. Probst et al. [6] compared healthy individuals with shaker- 2 mice and found that the cause of the impaired hearing was a mutation in the gene MYO15A. A G>A mutation causes a Cyst/Tyr substitution in the motor domain of the protein, which in turn leads to shortening of the stereocilia. Rak et al. [8] used human cDNA to design primers specific for the dog. PCR yielded a product of 201 bp containing only canine DNA. In addition, a FISH reaction was carried out in order to map the position of $M Y O 15 A$ on chromosome 5 in the $\operatorname{dog}$ (CFA5). Mapping of MYO15A on chromosome CFA5q23-q24 showed homology to HSA17p11.2-p13 in humans. This gene, located on HSA17p11.2, was selected for mapping as a candidate for congenital asymptomatic deafness in dogs. The study showed that mutations in MYO15A in the dog can lead to the occurrence of congenital deafness in these animals.

Analysis of expression of mouse tissue cDNA detected an mRNA transcript of myosins 1a, 1b, 1c, 1d, 1e, 1f, 1h, 3a, 3b, 5a, 6, 7a, 7b, 10, 15a, 16 and 18a [11-14]. Of these, at least 6 myosins are essential for hearing, as mutations in the genes $M Y O 1 A$, $M Y O 2 A, M Y O 2 B, M Y O 6, M Y O 7 A$ and $M Y O 15 A$ cause deafness in humans and mice $[14,15,16]$. Despite the store of genetic and expression data, the location of only seven myosins is known. Endogenous mouse myosin $1 \mathrm{~b}$ was found to be present in 
helper cells, and myosin 1e was localized in sensory cells [13]. Endogenous myosin 5a was detected in afferent neurons in the guinea pig. Myosin 6 has not been identified in stereocilia, but is present in sensory cells [11]. Myosin 1c, 7a and 15a are localized within of bundles of stereocilia in sensory cells $[3,11,17,18]$.

Myosin 15a [MYO15A] was one of the first proteins implicated in the regulation of stereocilia growth and acts together with the protein whirlin in this process. A link between myosin and whirlin was based on genetic research that showed hearing loss in humans with a mutation in MYO15A and the whirlin gene. Mutations in mouse genes have led to shortening of the stereocilia $[15,19]$.

MYO15A binds whirlin and both proteins are located at the tips of the stereocilia [18, $20,21,22]$. Whirlin is no longer present on the stereocilia tips in mice with defective MYO15A, which suggests that MYO15A transports whirlin [20]. Whirlin binds the proteins MAGUK p55 and 4.1R, which are expressed in the outer hair cells. The homologue of $4.1 \mathrm{R}$ in the inner hair cells is the protein 4.1B [19]. Many of these proteins regulate actin cytoskeletal assembly in the erythrocytes and neurons and may have similar functions in sensory cells [23,24].

The genetic testing of the wild and farmed canids (red fox and raccoon dog) revealed the presence of four SNP polymorphisms in the gene MYO15A. In the wild foxes living in Poland two haplotypes, $\mathrm{A}$ and $\mathrm{C}$, were distinguished based on a mutation at position c.426 $(A>G)$, while the wild Canadian foxes had a mutation at c.463 $(G>A)$ and were the only group with haplotype D. No SNP polymorphism was noted among the wild raccoon dogs, which may indicate the elimination of individuals with hearing disorders by natural selection. This probably indicates that the mutations occurring in the fox did not cause hearing impairment in the individuals tested, as such animals would be unable to survive in the wild.

One mutation was detected at position c.578 (C>A) in farmed foxes - haplotype $\mathrm{B}$, and only one mutation was detected in farmed raccoon foxes as well, at position c.432 (A>G) - haplotype A. Because these animals lived in farm conditions ensuring their food supply and protection from other individuals, their hearing may have been impaired in varying degrees. This may indicate that the mutations occurring in the gene MYO15A (at positions c.426 and c.463) in farmed individuals can contribute to hearing loss in these animals. For farmed animals a keen sense of hearing is not an essential condition for survival.

Recent years have seen considerable progress in the genetics of animals belonging to the Canidae family. The first complete canine karyotype and ideogram was published in 1999. Hybridization maps of genes and chromosomes were used to develop numerous microsatellite markers for searching an entire genome, and in 2003 sequencing of a female Boxer genome was begun. Today, owing to accumulation of data on the dog genome online, SNP microarray analyses can be created. At the same time, mutations affecting diverse traits are identified. Most of these variations are responsible for monogenic hereditary diseases in canids. Molecular tools have proven very useful in 
studying the population structure of dog breeds in order to reveal complex genetic traits [25].

Single-nucleotide polymorphism is an ideal marker characterizing genomic diversity, but can be difficult to detect in non-model animal species. Genetic differentiation between wild and farmed animals of the Canidae family is confirmed by research by Bugno-Poniewierska et al. using the FISH technique [26,27]. Studies on variation in wild and farmed individuals of different Canidae species have been and continue to be carried out at many levels, including diversity of morphological and physiological parameters and of phenotypic characteristics, as well as at the molecular and cytogenic level $[28,29]$. The usefulness of the dog genome for determining SNPs in genomes of distant Canidae species has been studied. Sacks and Louie [30], using 40 different primers, sequenced $80-88 \%$ of loci in the coyote (Canis latrans), the gray fox (Urocyon cinereoargenteus) and the red fox (Vulpes vulpes), which they then compared, demonstrating $60 \%$ similarity for these species. Mutations in the myosin 15a gene [MYO15 $A$ ] cause congenital deafness in humans and mice. For this reason $M Y O 15 A$ may be a candidate gene in which mutations may be responsible for hearing loss in the Canidae family (including dogs).

\section{REFERENCES}

1. Berg JS, Powell BC, Cheney RE: A millennial myosin census. Mol Biol Cell 2001, 12:780794.

2. Nal N, Ahmed MZ, Erkal E, Alper MO, Luleci G, Dinc O, Waryah MA, Ain Q, Tasneem S, Husnain T, Chattaraj P, Riazuddin S, Boger E, Ghosh M, Kabra M, Riazuddin S, Morell JR, Friedman BT: Mutational spectrum of MYO15A: The large N-terminal extension of Myosin XVA is required for hearing. Hum Mutat 2007, 28:1014-1019.

3. Anderson WD, Probst JF, Belyantseva AI, Fridell AR, Beyer L, Martin MD, Wu D, Kachar B, Friedman BT, Raphael Y, Amper AS: The motor and tail regions of myosin XV are critical for normal structure and function of auditory and vestibular hair cells. Hum Mol Gen 2000, 9:1729-1738.

4. Rędowicz JM: Myosina and pathology: genetics and biology. Act Bioch Polonica 2002, 49:789-804.

5. Kikkawa Y, Mburu P, Morse S, Kominami R, Townsend S, Brown MDS: Mutant analysis reveals whirlin as a dynamic organizer In the growing hair cell stereocilium. Hum Mol Gen 2005, 14:391-400.

6. Probst JF, Fridell AR, Raphael Y, Saunders LT, Wang A, Liang Y, Morell JR, Touchman WJ, Lyons HR, Trauth- Noben K, Friedman BT, Camper AS: Correction of deafness in shaker-2 mice by an unconventional Myosin in a BAC transgene. Science 1998, 280:14441447.

7. Rak GS, Dietl O: Congenital sensorineural deafness in dogs: A molecular genetic approach toward unraveling the responsible genes. Vet J 2005, 169:188-196.

8. Rak GS, Drogemuller C, Kuiper H, Leeb T, Quignon P, Ander C, Distl O: Cloning and chromosomal localization of MYO15A to chromosome 5 of the dog (Canis Familiaris). Chromosome Research, 2002, 10:407-410. 
9. Rozen S, Skaletsky H: Primer3 on the WWWW for general users and for biologist programmers. Methods Mol Biol, 2000, 132:365-386.

10. Shearer EA, Hildebrand SM, Webster AJ, Kahrizi K, Jalalvand K, Arzhanginy S, Kimberling JW, Stephen D, Bahlo M, Smith HJR, Najmabadi H: Mutations in the MyTH4 domain of MYO15A are a common cause of DFNB3 hearing loss. Laryngoscope, 2010, 119: 727-733.

11. Hasson T, Giilespie PG, Garcia JA, MacDonald RB, Zhao Y, Yee AG, Mooseker MS, Corey DP: Unconventional myosins in inner-ear sensory epithelia. J Cell Biol 1997, 137:1287-307.

12. Liang Y, Wang A, Belyantseva IA, Anderson DW, Probst FJ, Barber TD, Miller W, Touchman JW, Jin L, Sullivan SL, Sellers JR, Camper SA, Lloyd RV, Kachar B, Friedman TB, Fridell RA: Characterization of the human and mouse unconventional myosin XV genes responsible for hereditary deafness DFNB3 and shaker-2. Genomics 1996, 61:243-258.

13. Dumont RA, Zhao YD, Holt JR, Bahler M, Gillespie PG:, Myosin-I isozymes in neonatal rodent auditory and vestibular epithelia. J Assoc Res Otolaryngol 2002, 3:375-389.

14. Walsh T, Walsh V, Vreugde S, Hertzano R, Shahin H, Haika S, Lee MK, Kanaan M, King MC, Avraham KB: From flies' eyes to our ears: mutations in a human class III myosin cause progressive nonsyndromic hearing loss DNFB30. Proc Natl Acad Sci USA 2002, 99: 7518-23.

15. Wang A, Liang Y, Fridell RA, Probst FJ, Wilcox ER, Touchman JW, Morton CC, Morell RJ, Noben-Trauth K, Camper SA, Friedman TB: Association of unconventional myosin MYO15 mutations with human nonsyndromic deafness DFNB3. Science 1998, 280: 1447 51.

16. Donaudy F, Ferrera A, Esposito L, Hertzano R, Ben-David O, Bell RE, Melchionda S, Zelante L, Avraham KB, Gasparini P: Multiple mutations of MYO1A, a cochlear-expressed gene, in sensorineural hearing loss. Am J Hum Genet 2003, 72:1571-77.

17. Belyantseva IA, Boger ET, Friedman TB, Myosin XVa localizes to the tips of inner ear cell stereocilia and is essential for staircase formation of the hair bundle. Proc Natl Acad Sci USA 2003,100:13958-63.

18. Rzadzińska AK, Schneider ME, Davies C, Riordan GP, Kachar B: An actin molecular treadmill and myosins maintain stereocilia functional architecture and self-renewal. J Cell Biol 2004, 164:887-897.

19. Mburu P, Kikkawa Y, Townsend S, Romero R, Yonekawa H, Brown SD: Whirlin complexes with p55 at the stereocilia tip during hair cell development. Proc Natl Acad Sci USA 2006, 103:10973-78.

20. Belyantseva IA, Boger ET, Naz S, Frolenkov GI, Sellers JR, Ahmed ZM, Griffth AJ, Friedman TB, Myosin-XVa is required for tip localization of whirlin and differential elongation of hair-cell stereocilia. Nat Cell Biol 2005, 7:148-156.

21. Delprat B, Michel V, Goodyear R, Yamasaki Y, Michalski N, El-Amraoui A, Perfettini I, Legrain P, Richardson G, Hardelin JP, Petit C: Myosin XVa and whirlin, two deafness gene products required for hair bundle growth, are located at the stereocilia tips and interact directly. Hum Mol Genet 2005, 14:401-410.

22. Schneider ME, Dosé AC, Salles FT, Chang W, Erickson FL, Burnside B, Kachar B: A new compartment at stereocilia tips defned by spatial and temporal patterns of myosin IIIa expression. J Neurosci 2006, 24:5445-56.

23. Marfatia SM, Leu RA, Branton D, Chishti AH: Identifcation of the protein 4.1 binding interface on glycophorin $\mathrm{C}$ and $\mathrm{p} 55$, a homologue of the Drosophila discs-large tumor suppressor protein. J Biol Chem 1995, 270:715-719. 
24. Biederer T, Sudhof TC: CASK and protein 4.1 support F-actin nucleation on neurexins. J Biol Chem 2001, 276:47869-76.

25. Marschall Y, Distl O: Current developments in canine genetics. Berl Munch Tierarztl Wochenschr 2010, 123:325-338.

26. Bugno-Poniewierska M, Sojecka A, Pawlina K, Jakubczak A, Jezewska-Witkowska G: Comparative Cytogenetic Analysis of Sex Chromosomes in Several Canidae Species Using Zoo-FISH. Folia Biologica [Krakow] 2012, 60:11-16.

27. Bugno-Poniewierska M, Wroński M, Potocki L, Pawlina K, Wnuk M, Jeżewska-Witkowska G, Słota E: The Polymorphism of Cytogenetic Markers in the Farm and Wild-Living Raccoon Dog [Nyctereutes Procyonoides]. Annals of Animal Science 2013, 13:701-713.

28. Jeżewska-Witkowska G, Horecka B, Jakubczak A, Kasperek K, Ślaska B, BugnoPoniewierska M, Piórkowska M: Genetic variability of farmed and free-living populations of red foxes [Vulpes vulpes]. Annals of Animal Science 2012, 12:501-512.

29. Nowakowicz-Dębek B, Zoń A, Jakubczak A, Wnuk W: Hematological parameters of wild and farm mink, red fox and raccoon dog. Med Wet 2013. 69[1]:40-42.

30. Sacks BN, Louie S: Using the dog genome to find single polymorphisms in red foxes and other distantly related members of the Canidae. Mol Ecol Resour, 2008, 8:35-49.

\section{SNP GENETSKI DEVERZITET U OKVIRU FRAGMENTA GENA MYO15A, ODGOVORNOG ZA SLUH U POPULACIJI ŽIVOTINJA FAMILIJE CANIDAE U USLOVIMA FARMSKOG I SLOBODNOG UZGOJA}

JAKUBCZAK Andrzej, GRYZINSKA Magdalena, HORECKA Beata, DZIADOSZ Katarzyna, JEZEWSKA-WITKOWSKA Grazyna

Gen $M Y O 15 A$ je uključen u stvaranje proteina iz grupe motornih proteina - miozina. Miozin XVA je lociran u unutrašnjem uhu, hipofizi i drugim tkivima, i značajno utiče na slušni proces. Mutacije u ovom genu izazivaju supstitucije aminokiselina u konzervisanom motornom domenu lanca miozina, što dovodi do skraćenja stereocilija slušnih ćelija, a kao posledica dolazi do poremećaja funkcije XVA miozina. Postavljena je istraživačka hipoteza koja je pretpostavljala da mutacije u genu koji je odgovoran za slušni proces kod životinja familije Canidae mogu da izazovu hipoakustiku kao i značajne promene u ponašanju pasa, od povučenosti i straha do agresivnosti. Ispitivanjem je determinisan SNP polimorfizam u fragmentu gena MYO15A koji može da dovede do poremećaja sluha kako kod divljih tako i kod farmski uzgajanih životinja familije Canidae. 